\title{
Performance of Castor Bean Selects In Saline Sodic Soil
}

\author{
Ali Mohammed Oleiwi ${ }^{1}$, Medhat Mejeed Elsahookie ${ }^{2}$, Layla Ismail Mohammed ${ }^{2}$ \\ ${ }^{1}$ Directorate of Horticulture, Ministry of Agriculture, Baghdad, Iraq \\ ${ }^{2}$ College of Agriculture, University of Baghdad, Dept. of Crop Sciences, Baghdad, Iraq
}

Email address:

saadflaih@yahoo.com (L. I. Mohammed)

${ }^{*}$ Corresponding author

\section{To cite this article:}

Ali Mohammed Oleiwi, Medhat Mejeed Elsahookie, Layla Ismail Mohammed. Performance of Castor Bean Selects In Saline Sodic Soil. International Journal of Applied Agricultural Sciences. Vol. 2, No. 4, 2016, pp. 64-68. doi: 10.11648/j.ijaas.20160204.14

Received: May 31, 2016; Accepted: June 6, 2016; Published: June 20, 2016

\begin{abstract}
To determine the influence of selection on castor bean plants tolerance to saline sodic soil, three planting methods were used; in the bottom of furrow, at the side of furrow, and in rows of plots. The soil was saline sodic $(\mathrm{pH}<8.4, \mathrm{SAR}>13$, $\mathrm{Ec}>4 \mathrm{dS} / \mathrm{m}$ ), the cultivar of castor bean was Hindi 21. The experiments were conducted in 2010 and 2011 on the farm of Field Crops, Coll. of Agric., Univ. of Baghdad. At maturity, selected plants of those gave higher seed yield were harvested from each treatment. Selection pressure used on plant populations was $10 \%$. In the second year, seeds from each of the three treatments with the control were planted on the same field with 53 and 89 thousand plants/ha. The design used was a factorial with RCBD of three replicates. The results revealed that selected plants from row planting out yielded the other three treatments in seed yield/plant, seed no./plant, seed weight and harvest index. The values were $61 \mathrm{~g}, 251 \mathrm{seeds}, 0.25 \mathrm{~g}$, and $9.9 \%$, respectively. The lower planting density gave higher plant seed yield, seed no./plant and harvest index (55.6 g, 281 seeds, 8.0\%). It was concluded that selection on individual plants from planting in rows was effective to create a new variation in castor bean tolerance to saline sodic soil. The higher percent of heritability was in total dry matter (98.9\%), crop growth rate (98.4\%), and plant seed yield $(96.8 \%)$. That was indicating that genetic variance has the significant influence in phenotypic variance.
\end{abstract}

Keywords: Planting Methods, Population Densities, Heritability

\section{Introduction}

High percent of Iraqi soils is sodic, saline, or saline sodic. Selection tolerant plants for abiotic stress in the field has several difficulties for interacting other factors with the variable under study, here is salinity and high sodium in the soil. Among those factors are, soil $\mathrm{pH}$, nutrients, organic matter, available water, plant growth stage, and etc. Accordingly, several researchers have studied several traits related to abiotic stress. Elsahookie [1] reported many traits related to abiotic tolerance in plants. Khan et al. [2] studied heritability of root length of plants grown under salinity, and found that additive gene action was greater than non-additive in salinity tolerance. However, in general, plant abiotic stress tolerance is thought to be governed by quantitative inheritance [1].

Castor bean (Ricinus communis L.) is considered somewhat tolerance to saline and sodic soils than many other summer crops. Castor beans contain high percent of oil which make this crop has the priority to be used in hundreds of industries [3, 4]. Khan and Panda [5] reported that antioxidants in castor bean is not related to salinity tolerance. Seedling growth of castor bean (at 4 leaves) grown in saline medium between $50-200 \mathrm{dS} / \mathrm{m}$ of sodium chloride were reduced in root and shoot growth with increasing salinity [6]. However, Jeschke and Wolf [7] reported a stable growth of this crop when grown under different salinities. Li et al. [8] concluded that castor bean is negatively influenced with salinity. This work was conducted on a locally used cultivar of castor bean (Hindi 21) to find out some variations in the cultivar populations in salt tolerance grown in a saline sodic soil and select tolerant plants, then grown in two population densities in the same saline-sodic soil for evaluation.

\section{Materials and Methods}

On the farm of the College of Agric., University of Baghdad, Abu Graib, field experiments were undertaken in 
2010 and 2011. The soil was affected with saline sodic $(\mathrm{pH}<$ $8.4, \mathrm{SAR}>13, \mathrm{Ec}>4 \mathrm{dS} / \mathrm{m})$, the cultivar Hindi 21 of castor bean (Ricinus communis L.) was used. The soil was plowed, disc - furrowed, and the plots and furrows were prepared. Fertilizers added were compound NP (18\% N and 19\% P) of a rate of $400 \mathrm{~kg} / \mathrm{ha}$, and $200 \mathrm{~kg} / \mathrm{ha}$ of urea $(46 \% \mathrm{~N})$. At anthesis, $200 \mathrm{~kg} /$ ha of urea was applied.

\subsection{First Season}

On the soil mentioned before, three methods of planting were applied; planting in the bottom of furrow, planting on the side of furrow, and planting in rows in plots. Spacing used was $75 \times 25$ $\mathrm{cm}$. The dimensional of each experimental unit was $4.5 \times 2.25$ $\mathrm{m}$. Planting was in March 2010. Irrigation and weeding practices were done as needed. A total of 100 plants of each experimental unit of the 3 replicates were tagged as best tolerant plants, At harvest, 10 higher seed yield plants were selected out of each 100 plants tagged. Seeds of each selected sample were dried, weighed, and kept to the next year for planting and evaluation. Meanwhile, data on plant height, total dry matter, and plant seed yield were recorded on selected plants.

\subsection{Second Season}

On the same soil of previous season, a piece of land was prepared, and the selected seed lots were planted in furrows for evaluation. The size of experimental unit was $2.25 \times 2.5$ $\mathrm{m}$. Planting was in march, 2011. The seeds were planted into two planting population densities; 53 and 89 thousand plant/ha. The experiment involved selected seeds from the three planting methods plus the control as a fourth treatment. The design used was a factorial with RCBD with three replicates. Fertilization, weeding, and irrigation practices were done as in 2010 experiment. Data on plant height, number of branches, total dry matter and plant seed yield were recorded on five guarded plants taken randomly from each experimental unit. Plants sampled were cut into short parts and dried in oven at $75^{\circ} \mathrm{C}$ for $48 \mathrm{~h}$ [7]. Crop growth rate was estimated by using the formula; $C G R=(1 / A)$. (w2w1)/(T2-T1) reported by Salisbury [9]. Other traits shown in tables of results were also recorded.

\subsection{Genetic Analysis}

Some of genetic parameters were calculated by using method reported by Singh and Chaudhary [10]. The analysis of variance was analyzed as a fixed model. The genetic coefficient of variation (GCV) and phenotypic coefficient of variation $(\mathrm{PCV})$ were also determined as follows: GCV\% $=$ $(\sigma g / \bar{x}) \times 100$ and PCV\% $=(\sigma p / \bar{x}) \times 100$. The broad sense heritability was estimated by equation:

$$
H_{b . s}^{2} \%=\sigma^{2} g / \sigma^{2} g+\sigma^{2} e
$$

\section{Results and Discussion}

\subsection{Plant Height}

Data shown in Table 1 revealed that there were significant differences in plant heights due to the effect of genotypes planting population densities, and their interaction. Plants selected from the bottom of furrow gave higher plant height over the other three genotype plants. However, the control plants had the shortest plants. Castor bean plants grown in areas of semi - tropics may be reach a height of $1.5-30 \mathrm{~m}$ [11]. In general, castor bean grown in saline - sodic soils tends to have shorter height as compared to other soils without stress. Plants grown in population density of 53 thousands plant/ha gave higher height than those of 89 thousands plants/ha. The higher competition among plants grown in the higher density could be the reason. Meanwhile, the highest plant height obtained was from the plants selected from the bottom of the furrow and grown in the lower population density. However, the significance of the interaction between selected genotypes and population densities was due to the magnitude of response and not to direction of response, since all plants tended to be shorter when grown under higher population density.

Table 1. Plant height (cm) and total dry matter (g/plant) of castor bean genotypes grown under two population densities.

\begin{tabular}{|c|c|c|c|c|c|c|}
\hline \multirow{3}{*}{ Genotypes } & \multirow{2}{*}{\multicolumn{2}{|c|}{$\begin{array}{l}\text { Plant height } \\
\text { Plants/ha } x 1000\end{array}$}} & \multicolumn{4}{|c|}{ Total dry matter } \\
\hline & & & \multirow{2}{*}{ Mean } & \multicolumn{2}{|c|}{ Plants/ha x 1000} & \multirow{2}{*}{ Mean } \\
\hline & 53 & 89 & & 53 & 89 & \\
\hline Control & 165.33 & 157.00 & 161.17 & 454.0 & 341.7 & 397.8 \\
\hline Rows & 181.00 & 170.67 & 175.83 & 662.3 & 573.0 & 617.7 \\
\hline Furrow side & 175.33 & 168.33 & 171.83 & 829.0 & 821.3 & 825.2 \\
\hline Furrow bottom & 192.33 & 175.00 & 183.67 & 951.3 & 922.3 & 936.8 \\
\hline 1.s.d. $5 \%$ & 2.96 & \multirow{3}{*}{167.75} & 2.10 & 42.28 & \multirow{3}{*}{664.6} & 29.89 \\
\hline Mean & 178.50 & & & 724.2 & & \\
\hline 1.s.d. $5 \%$ & 1.48 & & & 21.14 & & \\
\hline
\end{tabular}

\subsection{Total Dry Matter}

The trends of response of plant dry matter is similar to that of plant height (Table 1). Plants selected from the bottom of furrow out yielded other plants of the three genotypes in total dry matter. At the same time, plants of the control gave the lowest total dry matter. The next selected plants of high total dry matter were those taken from side of the furrow treatment which ranked second after those selected from the bottom of the furrow. Khan and Panda [12] stated that this method of planting (bottom of the furrow) could help plants to have some level of balance between oxidative agents and antioxidants in plant tissues. Plants of high content of antioxidants would have better tolerance to stresses [13]. Results shown in Table 1 indicate that the lower planting population gave heavier plant dry weight. The result of having lower dry weight at high planting population as compared to low planting population was reported by some researchers $[2,14]$. In general, plants grown in saline - sodic soil suffer of less available water and less available nutrients plus the negative effects of toxic salts on growth of plants. So, when population density increased, plant growth will be more restricted under that stress, due to plant competition. On the other side, more chlorine and sodium in saline soil will limit plant growth [15]. It was noted that less effect of higher population density on total dry weight was in plants selected from bottom and side of the furrow. In 
case of plants of side of the furrow they gave 829.0 and 821.3, and plants of bottom of the furrow gave 951.3 and 922.3 g/plant when grown under 53 and 89 thousands plant/ha, respectively. The other two genotypes lost significant weight when grown at higher density. Stability of selected plants of any genera or species under different growth variables is a very required trait.

\subsection{Number of Branches}

Number of branches /plant has been significantly increased by selection (Table 2). Plants selected from the bottom of furrow gave higher number of branches per plant than the others. Plants of the control treatment had the lowest number. Number of branches in castor bean plants is counting on genotype and growth factors available. Genotypes of one or two branches are considered as weak plants, 3-5 moderate, and over 5 branches are branched genotypes [8, 10]. Accordingly, the local cultivar (Hindi 21) used in this study is considered as a branched cultivar. Salinity and sodium in the soil reduced number of branching as shown in Table 2 . Planting castor bean in population of 53 thousands plant/ha gave higher branches per plant than plants grown at higher population density due to less competition in lower density. The interaction between genotypes and population density was significant. The highest number of branches/plant was of those selected from bottom of furrow and planted in lower population density. It gave 9.43 branches/plant compared to the control cultivar that gave only 1.8 branches/ha when planted with higher density.

Table 2. Number of branches/plant and crop growth rate $\left(\mathrm{g} / \mathrm{m}^{2} / \mathrm{d}\right)$ of castor bean genotypes grown under two population densities.

\begin{tabular}{llllllll}
\hline \multirow{2}{*}{ Genotypes } & \multicolumn{3}{l}{ Branch/plant } & \multicolumn{4}{l}{ Crop growth rate } \\
\cline { 2 - 3 } & \multicolumn{2}{l}{ Plants/ha x 1000 } & \multirow{2}{*}{ Mean } & \multicolumn{3}{l}{ Plants/ha x 1000 } & \multirow{2}{*}{ Mean } \\
\cline { 2 - 3 } & $\mathbf{5 3}$ & $\mathbf{8 9}$ & & $\mathbf{5 3}$ & $\mathbf{8 9}$ & \\
\hline Control & 3.53 & 1.80 & 2.67 & 13.21 & 10.52 & 11.86 \\
Rows & 4.52 & 2.13 & 3.33 & 22.15 & 15.35 & 18.75 \\
Furrow side & 4.93 & 2.37 & 3.65 & 31.75 & 19.21 & 25.48 \\
Furrow bottom & 9.43 & 2.79 & 6.11 & 35.65 & 22.05 & 28.85 \\
1.s.d. 5\% & 0.88 & & 0.62 & 1.67 & & 1.18 \\
Mean & 5.61 & 2.27 & & 25.69 & 16.78 & \\
l.s.d. 5\% & 0.44 & & & 0.83 & & \\
\hline
\end{tabular}

\subsection{Crop Growth Rate}

Selecting castor bean plants grown under different methods of planting caused remarkable and significant differences among genotypes and the control in term of crop growth rate. Plants selected from those planted in the bottom of furrow had higher crop growth rate than all other three genotypes, Meanwhile, selection on plants grown by the three planting methods gave significant difference in crop growth rate over the control. It was also clear that lower population density used here gave significantly higher crop growth rate than that under higher population. When we check values of total dry matter (Table 1) we will find that selected plants in furrow bottom had higher value than other treatments, that was due to higher crop growth rate. It seems from data of crop growth rate (Table 2) that plants grown under higher population density were under high stress due to competition among plants and the abiotic stress of the negative effects of saline - sodic soil.

\subsection{Seed Weight}

Selected plants selected from row planting out byielded values of all other genotypes (Table 3). This shows that plants selected from furrow bottom gave vegetative growth better than others, but those selected from row planted castor bean gave better seed weight and better seed yield as we will see later. The lower 'planting population density gave lower seed weight. This could be attributed to higher crop growth rate, higher total dry matter, and higher branches/plant (Table 1 and 2). The interaction of genotypes with population densities was significant. The higher value of 100 seed weight was from plants selected from row planting and grown under 89 thousands plants/ha. It gave $28.67 \mathrm{~g} / 100$ seeds as compared to $18.67 \mathrm{~g}$ for the control plants grown under 53 thousands plants/ha.

\subsection{Number of Flower / Plants}

Data in Table 3 showed that selection on castor bean was effective to give significant variation in number of flower clusters/plant. This component is important to higher seed yield when it is coincided with high fertilization. Population densities did not show a significant difference in number of flower clusters/plant, and the interaction was not significant, but the only remarkable and significant effect was in plant selected from row planting. This selected genotype gave 7.45 flower cluster/plant and overcame all other values

Table 3. Seed weight (g/100 seed) and number of flower clusters/plant of castor bean genotypes grown under two population densities.

\begin{tabular}{|c|c|c|c|c|c|c|}
\hline \multirow{3}{*}{ Genotypes } & \multicolumn{3}{|c|}{ g/100 seeds } & \multicolumn{3}{|c|}{ flower cluster/plant } \\
\hline & \multicolumn{2}{|c|}{ Plants/ha x 1000} & \multirow{2}{*}{ Mean } & \multicolumn{2}{|c|}{ Plants/ha x 1000} & \multirow{2}{*}{ Mean } \\
\hline & 53 & 89 & & 53 & 89 & \\
\hline Control & 18.67 & 20.67 & 19.67 & 5.30 & 4.00 & 4.65 \\
\hline Rows & 22.33 & 28.67 & 25.50 & 8.00 & 6.80 & 7.45 \\
\hline Furrow side & 18.67 & 22.33 & 20.50 & 6.00 & 5.40 & 5.70 \\
\hline Furrow bottom & 19.67 & 27.33 & 23.50 & 5.80 & 4.50 & 5.15 \\
\hline 1.s.d. $5 \%$ & 2.42 & & 1.71 & n.s & & 0.62 \\
\hline Mean & 19.83 & 24.75 & & 6.28 & 5.18 & \\
\hline 1.s.d. $5 \%$ & 1.21 & & & n.s & & \\
\hline
\end{tabular}

\subsection{Seeds No. and Seed Yield/Plant}

Number of seeds/plant or unit area and seed weight give the total seed yield of the plant or unit area wich summarized in Table 4 shows that selected plants from row planted had significantly highest number of seeds/plant (250.7). However, this value became 321.0 seeds/plant when grown under 53 thousands plant/ha. This value was significantly higher than other values of the interaction of genotypes $\mathrm{x}$ planting density. At the same time, the lower planting density gave significantly higher number of seeds/plant that those planted under higher planting density. The lowest number of seeds/plant was obtained from control plants grown under higher planting density. 
Table 4. Number of seeds/plant and plant seed yield (g/plant) of castor bean genotypes grown under two population densities.

\begin{tabular}{lllllll}
\hline \multirow{2}{*}{ Genotypes } & \multicolumn{2}{l}{ Seeds/plant } & \multicolumn{3}{l}{ Seed yield (g/plant) } \\
\cline { 2 - 3 } & \multicolumn{2}{l}{ Plants/ha x 1000 } & \multirow{2}{*}{ Mean } & \multicolumn{2}{l}{ Plants/ha x 1000 } & \multirow{2}{*}{ Mean } \\
\cline { 2 - 3 } \cline { 5 - 6 } & $\mathbf{5 3}$ & $\mathbf{8 9}$ & & $\mathbf{5 3}$ & $\mathbf{8 9}$ & \\
\hline Control & 225.3 & 151.0 & 188.2 & 41.33 & 31.00 & 36.17 \\
Rows & 321.0 & 180.3 & 250.7 & 73.00 & 51.00 & 61.00 \\
Furrow side & 300.7 & 171.0 & 235.8 & 56.33 & 36.33 & 45.83 \\
Furrow bottom & 276.0 & 192.3 & 234.2 & 53.00 & 50.33 & 51.67 \\
1.s.d. 5\% & 11.9 & & 8.4 & 4.49 & & 3.18 \\
Mean & 280.8 & 173.5 & & 55.67 & 42.17 & \\
l.s.d. 5\% & 6.0 & & & 2.25 & & \\
\hline
\end{tabular}

Seed yield in general is a complex trait related to high number of genes, but no specific yield genes known. Ashraf and Harris [16] reported that response of plants to salinity differs according to species and cultivar, and the level of other variables such as; temperature, water, toxicity...etc and their interactions. It can be noted from Table 4 that selection on plants grown in rows gave higher value in term of plant seed yield. The higher value of plant seed yield (73.0 g) was obtained from this select when grown under lower population density. This genotype gave seed yield more than double when compared to the control plants grown under higher planting density. On the average across planting densities, it gave $61.0 \mathrm{~g} / \mathrm{plant}$ and out yielded all other genotypes. The data of Table 4 showed that planting castor bean in that type of soil (saline - sodic) was better under lower planting density (53 thousands/ha).

The significant interaction of genotype $\mathrm{x}$ planting density was due to the magnitude of response and not to direction of response. All values tended to be lower in seed yield when grown under higher planting density including the control plants.

\subsection{Harvest Index}

Castor bean plants selected from row planting treatment gave significantly higher harvest index as compared to other genotypes (Table 5). The lowest two values were of plants selected from bottom and side of furrow. The low population density gave higher harvest index than the high one. The interaction between genotypes $\mathrm{x}$ population density was significant. On the other side, plants selected from row planting and grown at the low population density gave the highest harvest index. In general, harvest indices of castor bean were low because of the negative effects of saline sodic soil.

Table 5. Values of harvest index of castor bean genotypes grown under two population densities.

\begin{tabular}{llll}
\hline \multirow{2}{*}{ Genotypes } & \multicolumn{3}{l}{ Harvest index (\%) } \\
\cline { 2 - 3 } & \multicolumn{2}{l}{ Plants/ha x $\mathbf{1 0 0 0}$} & \multirow{2}{*}{ Mean } \\
\cline { 2 - 3 } & $\mathbf{5 3}$ & $\mathbf{8 9}$ & 9.06 \\
\hline Control & 8.99 & 8.88 & 9.88 \\
Rows & 10.96 & 8.92 & 5.54 \\
Furrow side & 6.62 & 4.40 & 5.55 \\
Furrow bottom & 5.48 & 5.43 & 0.80 \\
l.s.d. 5\% & 1.13 & & \\
Mean & 8.05 & 6.91 & \\
l.s.d. 5\% & 0.57 & & \\
\hline
\end{tabular}

\subsection{Genetic Parameters}

Table 6 shows data on ratio of genetic variance to phenotypic variance, genetic and phenotypic coefficients of variation and broad sense heritability of castor bean genotypes in study. The highest value of genetic variance to phenotypic variance was with total dry matter and crop growth rate. They were 96.9 and 62.1, respectively. Other values were lower, especially of number of flower clusters per plant. Values of genetic coefficient of variation and phenotypic coefficients of variation of the traits studied were somewhat similar. However, the traits that gave high and similar values of these two coefficients were branches/plant, total dry matter, seed yield, crop growth rate and harvest index. These high values of traits indicate their role in abiotic stress tolerance. Some other researchers found similar values on cotton (Gossypium hirsutum L.) and explained the benefit of these parameters for plant seeds $[17,18]$. Values of broad sense heritability were almost high for most of traits studied (90\% to $98 \%$ ) except for seed weight $(79.5 \%)$ and number of flower clusters $(29.0 \%)$ which already gave 0.41 ratio of genetic/phenotypic variance.

As it was noticed from results showed in Tables 1-6, selection for better growth and high seed yield of castor bean plants was effective. Methods of planting castor bean were quite different in showing population variation in growth parameters and seed yield. Planting castor bean in rows was the best method for selecting better plants tolerant to stresses of saline - sodic soils. The most important traits to be considered in selection program could be plant height, total dry matter, seeds/plant, seed yield, and crop growth rate. Crop growth rate and dry matter may be studied according to two or three plant growth stages, that will help to investigate the poor and the best stage of tolerance to abiotic stress. In Iraq, summer temperature exceeds $50 \stackrel{\circ}{\mathrm{C}}$ for several days, this will alleviate the negative effect of salinity and sodicity, since that will retard cell division and size $[19,20]$. So, the date of planting of this crop could be considered in such a program.

Table 6. Ratio of genetic variance to phenotypic variance, genetic and phenotypic coefficients of variation and broad sense heritability of castor bean traits.

\begin{tabular}{lllll}
\hline $\begin{array}{l}\text { Trait } \\
\text { studies }\end{array}$ & $\begin{array}{l}\text { genetic variance } \\
\text { /phenotypic } \\
\text { variance }\end{array}$ & $\begin{array}{l}\text { phenotypic } \\
\text { coefficients of } \\
\text { variation\% }\end{array}$ & $\begin{array}{l}\text { genetic } \\
\text { coefficients } \\
\text { variation } \%\end{array}$ & $\begin{array}{l}\text { broad } \\
\text { sense } \\
\text { heritability }\end{array}$ \\
\hline $\begin{array}{l}\text { plant height } \\
\text { branch/plant }\end{array}$ & 30.50 & 5.48 & 5.40 & 96.83 \\
$\begin{array}{l}\text { Total dry } \\
\text { matter }\end{array}$ & 96.90 & 39.93 & 37.86 & 89.90 \\
$\begin{array}{l}\text { Flower } \\
\text { cluster/plant }\end{array}$ & 0.41 & 34.40 & 34.22 & 98.98 \\
$\begin{array}{l}\text { Seed weight } \\
\begin{array}{l}\text { Seed/plant } \\
\text { Plant seed }\end{array}\end{array}$ & 15.65 & 34.91 & 18.80 & 29.03 \\
$\begin{array}{l}\text { yield } \\
\text { Crop } \\
\text { growth rate }\end{array}$ & 17.60 & 13.37 & 11.84 & 79.48 \\
$\begin{array}{l}\text { Harvest } \\
\text { index }\end{array}$ & 12.58 & 12.22 & 11.85 & 94.00 \\
\hline
\end{tabular}




\section{References}

[1] Elsahookie, M. M. 2013. Breeding Crops for Abiotic Stress: A Molecular Approach and Epigenetic. Coll. of Agric., Univ. of Baghdad.pp. 244.

[2] Kamel, L., I. Kande, B. A. El. Ahmer, and S. I. Elmohandes. 1985. Effect of nitrogen level and plant population on sunflower. Anns. of Agric. Sci., Moshtohor 23:(2) 502-511.

[3] Lima, G. S., R. G. Nobre, H. R. Gheyi, L. A. A. Soares and E. M. Silva. 2015. Irrigation water salinity and nitrogen doses affect the cultivation of castor bean (Ricinus communus L.) at different phonological stages. Australian J. of Crop Sci. 9(9): 870-878.

[4] Jeschke, W. D. and O. Wolf. 1988. Effect of $\mathrm{NaCl}$ salinity on growth, development, ion distribution and ion translocation in castor bean (Ricinus communis L.). J. of Plant Physiology. 132(1): 45-53.

[5] Khan, A., S. Rao, and T. McNeilly. 2003. Assessment of salinity tolerance based upon seedling root growth response function in maize. Euphytica. 131: 81-89.

[6] Gautam, R.C., and K.C. Sharma. 1987. Dry matter accumulation under different planting schemes and plant densities of rice. Indian J. Agric. Res. 21(2): 101-109.

[7] Janmohammed, M., A. Abbasi and N. Sabaghnia. 2012. Influence of $\mathrm{NaCl}$ treatments on growth and biochemical parameters of castor bean (Ricinus communis L.). Acta Agriculturae Slovenica. 99(1): 31-40.

[8] Li, G., H. Zhang, X. Wu, C. Shi, X. Huang and A. Qin. 2011. Canopy reflectance in two castor been varieties (Ricinus communus L.) for growth assessment and yield prediction on coastal saline land of Yancheng district, China. Industrial Crops and Products. 33: 395-402.journal homepage: www.elsevier.com/locate/indcrop.

[9] Rezek, T. Y, and H. A. Ali. 1982. Oil and Sugar Crops. Ministry of Higher Education and Scientific Research. Iraq. pp. 592.

[10] Singh, R.K., and Chaudhary. 1985. Biometrical Methods in Quantitative Genetic Analysis. Kalyani Publishers, New Delhi, Ludhiana. pp. 318.

[11] Dimova, R. and D. Dekov. 1990. Field Crops of Tropic and Semitropic Areas. Ministry of Higher Education and Scientific Research. Iraq. Translated by K. I. M. Ali.pp.432.

[12] Khan, M. H. and S. K. Panda. 2008. Alterations in root lipid peroxidation and antioxidative responses in two rice cultivars under NaCl-salinity stress. Acta Physiologiae Plantarum. 30: 250-255.

[13] Parida, A. K. and A. B. Das. 2005. Salt tolerance and salinity effects on plants. Ecotoxicology and Environmental Safety.60324-349.

[14] Aziz, F. O. 2008. Breeding Sunflower, Sorghum, and Maize by Hoeycomb. Ph. D. Dissertation, Dept. of Field Crop Sci., College of Agric., Univ. of Baghdad, pp. 90.

[15] Flowers, T.J. 2004. Improving crop salt tolerance. J. Exp. Bot. 55: 307-319.

[16] Ashraf, M. and P. J. C. Harris. 2004. Potential biochemical indicators of salinity tolerance in plants. Plant Sci. 166: 3-16.

[17] Preetha, S. and T. S. Raveendran. 2007. Genetic variability and association analysis in three different morphological groups of cotton (Gossypium hirsutum L.). Asian Journal of Plant Sciences. 6(1): 122-128.

[18] Soomro, Z. A., M. B. Kumbhar, A. S. Larik, M. Imran and S. A. Brohi. 2010. Heritability and selection response in segregating generations of upland cotton. Pakistan J. Agric. Res. 23(1-2): 25-30.

[19] Elsahookie, M. M. and M. I. Al-Khafajy. 2014. Mechanism of plant salinity stress tolerance. The Iraqi. J. Agric. Sci. 45(5): 430-438.

[20] Salisbury, F.B. 1996.Units, Symbols, and Terminology for Plant Physiology. New York, Oxford, Oxford University Press. pp. 234. 